A. Č. Majhenič $\cdot$ K. Venema $\cdot$ G. E. Allison •

B. B. Matijašić · I. Rogelj • T. R. Klaenhammer

\title{
DNA analysis of the genes encoding acidocin LF221 A and acidocin LF221 B, two bacteriocins produced by Lactobacillus gasseri LF221
}

Received: 19 May 2003 / Revised: 14 July 2003 / Accepted: 18 July 2003 / Published online: 18 September 2003

C) Springer-Verlag 2003

\begin{abstract}
Lactobacillus gasseri LF221, an isolate from the feces of a child, produces two bacteriocins. Standard procedures for molecular techniques were used to locate, clone and sequence the fragments of LF221 chromosomal DNA carrying the acidocin LF221 A and B structural genes, respectively. Sequencing analysis revealed the gene of acidocin LF221 A to be an open reading frame encoding a protein composed of 69 amino acids, including a 16-amino-acid N-terminal extension. The acidocin LF221 B gene was found to encode a 65-amino-acid bacteriocin precursor with a 17 -amino-acid N-terminal leader peptide. DNA homology searches showed similarities of acidocin LF221 A to brochocin B, lactococcin N and thermophilin B, whereas acidocin LF221 B exhibited some homology to lactacin $\mathrm{F}$ and was virtually identical to gassericin $\mathrm{X}$. The peptides encoded by $\operatorname{orf} \mathrm{A} 1$ and $\operatorname{orf} \mathrm{B} 3$ showed characteristics of class II bacteriocins and are suspected to be the complementary peptides of acidocin A and $\mathrm{B}$, respectively. orf $\mathrm{A} 3$ and $\operatorname{orf} \mathrm{B} 5$ are proposed to encode putative immunity proteins for the acidocins.
\end{abstract}

A. Č. Majhenič $(\bowtie) \cdot$ B. B. Matijašić $\cdot$ I. Rogelj

Chair of Dairy Science, Zootechnical Department, Biotechnical Faculty, University of Ljubljana,

Groblje 3,

1230 Domžale, Slovenia

e-mail: andreja.canzek@bfro.uni-lj.si

Tel.: +386-1-7217844

Fax: +386-1-7214074

K. Venema

Department of Nutritional Physiology, TNO Nutrition and Food Research,

P.O. Box 360, 3700 AJ Zeist, The Netherlands

G. E. Allison

Department of Agricultural, Food and Nutritional Science, University of Alberta,

410 Agriculture/Forestry Center,

Edmonton, Alberta, T6G 2P5, Canada

T. R. Klaenhammer

Department of Food Science, Southeast Dairy Foods Research Center, North Carolina State University,

Raleigh, NC 27695-7624, USA
Acidocin LF221 A and acidocin LF221 B are predicted to be members of the two-component class II bacteriocins, where acidocin LF221 A appears to be a novel bacteriocin. L. gasseri LF221 is being developed as a potential probiotic strain and a food/feed preservative. Detailed characterization of its acidocins is an important piece of background information useful in applying the strain into human or animal consumption. The genetic information on both acidocins also enables tracking of the LF221 strain in mixed populations and complex environments.

\section{Introduction}

Lactic acid bacteria (LAB) inhabit diverse ecosystems, including the human and animal gastrointestinal tracts and mucosal surfaces and other environments (grapes, vegetables, milk, meat) where fermentation of available carbohydrates occurs. For successful survival in such highly populated and competitive microbial niches, LAB may produce antagonistic antimicrobial compounds, including ribosomally synthesized peptides, termed bacteriocins (Moll et al. 1999; Teuber et al. 1999). Bacteriocins are proteins or protein complexes that show bactericidal activity against species that are closely related to the producer bacteria (Tagg et al. 1976). At present, biochemical and genetic characteristics divide bacteriocins in three different classes: (I) lantibiotics and (II) nonlantibiotics which are both small, membrane-active and heat-stable and (III) large, heat-labile proteins (Moll et al. 1999). The class II antimicrobial peptides, produced as bacteriocin precursors which are activated with cleavage at the Gly-Gly ${ }^{-1}$ processing site, can be subdivided into: (IIa) listeria active peptides with a consensus sequence in the $\mathrm{N}$-terminus of -T-G-N-G-V-X-C-, represented by pediocin PA-1, (IIb) poration complexes consisting of two proteinaceous peptides where both peptides are necessary for full activity, for example lactococcin $G$, lactococcin $M$ and lactacin F, (IIc) bacteriocins translated with sec-dependent leaders and (IId) bacteriocins that do not belong to subgroups IIa-IIc (Klaenhammer 1993; Moll et al. 1999). 
For many years, Lactobacillus acidophilus was considered the most prominent species of intestinal lactobacilli, but recent developments in molecular methods revealed significant heterogeneity within the group. Based on DNA-DNA homologies and cell-wall composition, two main groups (A, B) were defined, including six distinct species within the previous $L$. acidophilus group: A-1 (L. acidophilus), A-2 (L. crispatus), A-3 (L. amylovorus), A-4 (L. gallinarum), B-1 (L. gasseri) and B-2 (L. johnsonii; Fujisawa et al. 1992; Johnson et al. 1980). It is now recognized that there are a number of important representatives of Lactobacillus species in human and animal intestines, including L. gasseri (Heilig et al. 2002; Mitsuoka 1992).

It is likely that bacteriocin production plays a role in the survival and persistence of these organisms in the gastrointestinal tract. A number of Lactobacillus bacteriocins and their genetic determinants have been described. Chromosomally encoded bacteriocin production has been reported for lactacin B (Barefoot and Klaenhammer 1983), gassericin T (Kawai et al. 2000) and gassericin A (Kawai et al. 1998), while genetic determinants for acidocin B (Leer et al. 1995), acidocin 8912 (Kanatani et al. 1995a) and acidocin A (Kanatani et al. 1995b) have been confirmed to be located on plasmids. Lactacin $\mathrm{F}$ is chromosomally encoded on a conjugative transposon that is mobilized as a large extrachromosomal element (Muriana and Klaenhammer 1987). Complete gene sequences allow the description and classification of novel bacteriocins and permit comparisons with other, already known, bacteriocins.

L. gasseri LF221 was isolated from a childs feces and was formerly named L. acidophilus LF221 (Bogovič Matijašić et al. 1998). This strain produces proteinaceous antimicrobials that exert an unusually wide antagonistic effect that inhibit not only lactobacilli but also strains of other genera, including Lactococcus, Pediococcus, Staphylococcus, Enterococcus, Streptococcus, Listeria, Clostridium and Bacillus. Two bacteriocins of the LF221 strain were purified previously and their N-terminal amino acid sequences were determined by Edman degradation (Bogovič Matijašić et al. 1998). The biochemical properties of the two LF221 acidocins, small, heat-stable and hydrophobic peptides, mostly resembled class II bacter- iocins (Bogovič Matijašić et al. 1998; Klaenhammer 1993).

In this study, we report the cloning and sequence analysis of the acidocin LF221 A and B genes of $L$. gasseri LF221. The characteristics of these genes and their surrounding loci are described.

\section{Materials and methods}

Bacterial strains and plasmids

Bacterial strains and plasmids used in this study are listed in Table 1. Cultures were maintained and stored at $-80^{\circ} \mathrm{C}$ in MRS broth (de Man et al. 1960) with $20 \%$ glycerol (v/v). The bacteriocin producer L. gasseri LF221 and its non-bacteriocinogenic mutant LF221-1 were propagated in MRS broth at $37^{\circ} \mathrm{C}$. Escherichia coli JM110 (Yanisch-Perron et al. 1985) was grown in LB broth (Sambrook et al. 1989) with shaking or on LB agar $(1.5 \% \mathrm{w} / \mathrm{v})$ at $37^{\circ} \mathrm{C}$. Kanamycin $(50 \mu \mathrm{g} / \mathrm{ml}$; Sigma, St. Louis, Mo.) was added to LB media for selection of $E$. coli JM110 transformants.

Isolation of plasmid and chromosomal DNA

Plasmid DNA was isolated from E. coli JM110 transformants by the alkaline lysis method of Birnboim and Doly (1979). Chromosomal DNA from $L$. gasseri LF221 and its Bac mutant were obtained by the modified protocol of Leenhouts et al. (1990). Briefly, $2 \mathrm{ml}$ of an overnight culture were centrifuged and the pellet was washed once with $1 \mathrm{ml}$ of sterile distilled water. Cells were treated with $0.5 \mathrm{ml}$ of lysis solution $(50 \mathrm{mM}$ glucose, $10 \mathrm{mM}$ EDTA, $25 \mathrm{mM}$ Tris-HCl, $\mathrm{pH} 8)$ containing lysozyme $(10 \mathrm{mg} / \mathrm{ml}$; Sigma) and the mixture was held at $55^{\circ} \mathrm{C}$ for $30 \mathrm{~min}$. After lysozyme treatment, $20 \mu \mathrm{l}$ of proteinase K (20 mg/ml; Sigma) and $25 \mu 1$ of $10 \%$ SDS were added. Incubation was continued at $60^{\circ} \mathrm{C}$ for at least $1 \mathrm{~h}$. The lysate was extracted twice with an equal volume of a phenol-chloroformisoamyl alcohol mixture (25:24:1) and once with an equal volume of chloroform-isoamyl alcohol $(24: 1)$. Ammonium acetate (3 M, $\mathrm{pH} 4.8)$ was added $(0.1 \mathrm{vol}$.) and the DNA was precipitated with 2 vol. of $96 \%$ ethanol $\left(-20^{\circ} \mathrm{C}\right)$. Precipitated DNA was washed once with $70 \%$ ethanol $\left(-20^{\circ} \mathrm{C}\right)$ and dissolved in $100 \mu$ of sterile distilled water containing RNase $(20 \mu \mathrm{g} / \mathrm{ml}$; Sigma). Resuspended DNA was incubated at room temperature for $30 \mathrm{~min}$. Plasmid DNA isolation from LF221 was performed by two different protocols. Alkaline lysis of L. gasseri LF221 was accomplished by the method of Sambrook et al. (1989) with minor modifications. LF221 cells were propagated for $9 \mathrm{~h}$ at $37^{\circ} \mathrm{C}$ in $100 \mathrm{ml}$ of MRS broth and centrifuged $(4,500 \mathrm{~g}, 10 \mathrm{~min})$. Pelleted cells were resuspended in $10 \mathrm{ml}$ of lysis buffer (pH 8), consisting of $100 \mathrm{mM}$ Tris- $\mathrm{HCl}, 10 \mathrm{mM}$ EDTA and $25 \%(\mathrm{w} / \mathrm{v})$ of sucrose. Lysozyme $(5 \mathrm{mg} / \mathrm{ml})$ and mutanolysin
Table 1 Bacterial strains and plasmids. NCDO National Collection of Dairy Organisms, National Institute for Research in Dairying, Shinfield, UK. ZIM Collection of Industrial Microorganisms, Ljubljana, Slovenia

\begin{tabular}{|c|c|c|}
\hline Strain or plasmid & Characteristics & Reference or source \\
\hline \multicolumn{3}{|l|}{ Bacterium } \\
\hline Lactobacillus gasseriLF221 & $\begin{array}{l}\text { Bacteriocinogenic strain }\left(\mathrm{Bac}^{+}\right) \\
\text {isolated from a child's feces }\end{array}$ & $\begin{array}{l}\text { Bogovič Matijašić et al. } \\
\text { (1998); ZIM BI50 }\end{array}$ \\
\hline L. gasseri LF221-1 & $\begin{array}{l}\text { Non-bacteriocinogenic derivative }\left(\mathrm{Bac}^{-}\right) \text {, } \\
N \text {-methyl- } N \text {-nitro- } \\
N \text {-nitrosoguanidine mutant }\end{array}$ & This study; ZIM BI43 \\
\hline Escherichia coli JM110 & Plasmid-free strain & Stratagene, Calif., USA \\
\hline $\begin{array}{l}\text { L. sakei NCDO } 2714 \\
\text { Vector }\end{array}$ & Bacteriocin-sensitive indicator strain & NCDO \\
\hline pCR-Blunt & $3.5 \mathrm{~kb}, \mathrm{Km}^{\mathrm{r}}$ & Invitrogen, Calif., USA \\
\hline
\end{tabular}


(25 units/ml; Sigma) were added. After the incubation of the cell suspension for $30 \mathrm{~min}$ at $37^{\circ} \mathrm{C}$, plasmid DNA isolation was carried out as described by Sambrook et al. (1989). For plasmid DNA isolation by the protocol of Klaenhammer (1984), mutanolysin (25 units $/ \mathrm{ml})$ and lysozyme $(5 \mathrm{mg} / \mathrm{ml})$ were added and the cells incubated for $2 \mathrm{~h}$ at either $37^{\circ} \mathrm{C}$ or in an ice bath. DNA isolation was continued as described by Klaenhammer (1984). Electrophoresis was conducted on $0.8 \%$ agarose gels in TAE buffer (Sambrook et al. 1989 ) at $\mathrm{pH} 8.2$ and $100 \mathrm{~V}$ for $30-45 \mathrm{~min}$.

\section{Selection of $\mathrm{Bac}^{-}$derivatives}

The genetic stability of bacteriocin production in L. gasseri LF221 was evaluated with treatment of LF221 in different ways. First, LF221 was repeatedly subcultured in MRS broth at $37^{\circ} \mathrm{C}$ over 14 days. Cultures were diluted, plated onto M17 agar (Merck) and incubated for $24 \mathrm{~h}$ at $37^{\circ} \mathrm{C}$ under microaerophilic conditions; and then the plates were overlaid with $4 \mathrm{ml}$ of MRS soft agar $(0.75 \% \mathrm{w} /$ v) seeded with $L$. sakei NCDO 2714. Single LF221 colonies were examined for zones of inhibition in the lawn of $L$. sakei. In a second attempt to select $\mathrm{Bac}^{-}$mutants, LF221 was propagated at sublethal temperatures of $55^{\circ} \mathrm{C}$ for 24,48 , or $72 \mathrm{~h}$ and then screening for mutants deficient in bacteriocin production, proceeding as outlined above. For treatment with $\mathrm{N}$-methyl- $\mathrm{N}$-nitro- $\mathrm{N}$-nitrosoguanidine (NTG; Sigma), which could induce deletions and base substitutions, $100 \mu \mathrm{l}$ of an 18-h LF221 culture was spread over M17 agar and a small crystal of NTG was placed on the surface. After incubation for $48 \mathrm{~h}$ at $37^{\circ} \mathrm{C}$, the colonies that grew on the edge of the zone of inhibition were selected and further examined for bacteriocin production.

\section{Degenerate primers and PCR reaction}

As both the acidocin LF221 A and acidocin LF221 B peptides had previously been purified and their $\mathrm{N}$-terminal sequence determined (Bogovič Matijašić et al. 1998), two degenerate primers were constructed for each of the two peptides based on this amino acid sequence. The degenerate primers for the acidocin LF221 A were bacA5 (5'-GGW AAR GGW GCW GTW ATG GA-3', corresponding to the amino acid sequence Gly $^{13}$-Lys-Gly-Ala-Val-Met-Glu ${ }^{19}$ ) and bacA3 (5'-WGT WGC WGC WCC RTT WGC-3', corresponding to $\mathrm{Ala}^{30}$-Asn-Gly-Ala-Ala-Thr ${ }^{35}$ ). For acidocin LF221 B, the degenerate primers bacB5 (5'-GGW GCW GCW ACW GGW GCW AC-3') and bacB3 (5'-GCW GTC ATW CCC CAW GGW CCR AA-3') were constructed (corresponding to amino acid sequences Gly ${ }^{9}$-Ala-Ala-Thr-Gly-Ala-Thr ${ }^{15}$ and Phe ${ }^{24}$-Gly-Pro-Trp-Gly-Met-

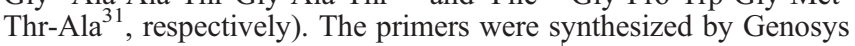
(Tex., USA). Chromosomal DNA of the $\mathrm{Bac}^{+}$parental strain and the $\mathrm{Bac}^{-}$derivative was used as the template in the PCR reactions. The PCR conditions were as follows: hot start at $94^{\circ} \mathrm{C}$ for $1 \mathrm{~min}$, annealing at $52^{\circ} \mathrm{C}$ for $30 \mathrm{~s}$ and polymerization at $72^{\circ} \mathrm{C}$ for $30 \mathrm{~s}$, through 35 cycles. The reagents and amounts used were as recommended in the Pwo DNA polymerase kit (Roche Molecular Biochemicals, Mannheim, Germany). Then, $10 \mu \mathrm{l}$ of the reaction mixture were electrophoresed on a $2.5 \%$ agarose gel and the amplicons were purified using the QIAquick PCR purification kit (Qiagen, Valencia, Calif.). These PCR fragments were coded ON-A and ON-B and were later used as oligonucleotide probes in nucleic acid hybridization to detect the structural genes of acidocin LF221 A and $\mathrm{B}$, respectively.

Oligonucleotides ON-A (69 bp) and ON-B (68 bp), were sequenced using the dideoxy-chain termination method of Sanger et al. (1977) and the 7-deaza-dGTP and T7 Sequenase DNA polymerase kit (Amersham, Ohio, USA). Purified PCR products were cloned into pCR-Blunt as outlined by the manufacturer (Invitrogen) and primers complementary to the pCR-Blunt multiple cloning site, BL1 (5'-GCATCAAGCTTGGTACCGAG-3') and BL2 (5'-CCCTCTAGATGCATGCTCG-3'), were used for sequencing.
Sequencing confirmed that the nucleotide sequence corresponded to the genes for the bacteriocins.

\section{Southern blot analysis}

Chromosomal DNA of LF221 and its Bac ${ }^{-}$mutant were single- and double-digested with several restriction enzymes according to directions supplied by the manufacturer (Roche) and separated on $1.0 \%$ agarose gel at $15 \mathrm{~V}$ overnight. Southern transfer of digested DNA from agarose gel to MagnaCharge Nylon membrane (Micron Separations, Westboro, Mass.) was done as described by Sambrook et al. (1989) and the DNA was fixed to the membrane by UV light (Stratalinker 1800, Stratagene). Oligonucleotide probes ON-A and ON-B for the LF221 acidocins were labeled with digoxigenin (DIG)-dUTP (Roche) in a PCR reaction using Taq DNA polymerase, according to the instructions of the manufacturer (Genius system users guide for membrane hybridization; Roche). Prehybridization and hybridization were conducted at $68^{\circ} \mathrm{C}$ for $2 \mathrm{~h}$ and overnight, respectively, as outlined by the DIG DNA labeling and detection kit (Roche).

\section{Molecular cloning and transformation}

The information from the Southern hybridizations was used to identify the size of the HindIII/BamHI and HindIII/EcoRI fragments containing the acidocin LF221 A and B genes, respectively. Total genomic DNA was digested with HindIII/BamHI and electrophoresed; and the approximate area in the gel corresponding to the predicted fragment containing the acidocin LF221 A gene was gelpurified using the QIAquick gel extraction kit (Qiagen). Ligation of purified fragments to pCR-Blunt (cut with HindIII and BglII) was conducted at $16^{\circ} \mathrm{C}$ overnight using T4 DNA ligase (Roche). Competent E. coli JM110 cells were prepared (Dinsmore and Klaenhammer 1997) and transformed with the ligation mix (Sambrook et al. 1989). After transformation, cells were incubated in appropriate non-selective media for $1 \mathrm{~h}$ prior to plating on selective LB agar plates containing kanamycin $(50 \mu \mathrm{g} / \mathrm{ml})$. Similarly, the region in the agarose gel containing the HindIII/ EcoRI-specific fragment for the acidocin LF221 B structural gene was purified and ligated to the HindIII/EcoRI-cut pCR-Blunt vector.

\section{Colony hybridization and nucleotide sequence}

For acidocin A cloning, about 700 transformants were transferred from selective LB agar to Whatman 541 filter paper (Whatman Ltd., Maidstone, UK). Cell lysis, denaturation and immobilization of DNA were performed as described by Gergen et al. (1979). Screening of the recombinant DNA was done with colony hybridization as described by Sambrook et al. (1989). The ON-A oligonucleotide was end-labeled with $\left[\gamma-{ }^{32} \mathrm{P}\right] \mathrm{dATP}$ (Amersham), using T4 polynucleotide kinase (Roche), and was used to probe the membranes. Putative positive clones were detected by autoradiography (Kodak X-Omat AR 5). Plasmid DNA was isolated from these clones, and analyzed by HindIII/BamHI digestion. Sequencing was used to confirm the presence and integrity of the cloned insert.

Attempts to transform the recombinant product of pCR-Blunt:: HindIII/EcoRI into competent E. coli JM110 were not successful. Therefore, PCR was performed on the ligated products with the vector-specific primers BL2 (see section Degenerate primers and PCR reaction) and BL5 (5'-ATGATTACGCCAAGCTATTTAGG$\left.3^{\prime}\right)$, and tail-to-tail oriented bacteriocin-specific primers BB1 (5'TACTCCGCGAGTAGCACCAG-3') and BB2 (5'-AGTTGGTGCAGAGGATTC- $3^{\prime}$ ) through 45 cycles, including DNA denaturation $\left(94^{\circ} \mathrm{C}, 1 \mathrm{~min}\right)$, annealing $\left(55^{\circ} \mathrm{C}, 1 \mathrm{~min}\right)$ and elongation $\left(68^{\circ} \mathrm{C}\right.$, $3 \mathrm{~min})$. PCR was accomplished with the Expand high fidelity PCR system (Roche). The PCR products were analyzed on agarose gel $(1.6 \%)$. Specific amplicons were purified from gel using the 
QIAquick gel extraction kit (Qiagen) and subjected to the sequencing reactions according to the procedure of Sanger et al. (1977). The DNA sequence was analyzed to ensure the genes corresponded to acidocin LF221 A and acidocin LF221 B.

The sequences were deposited in GenBank under accession numbers AY295874 and AY297947 for acidocin LF221 A and acidocin LF221 B, respectively.

\section{Speciation of LF221}

The V2-V3 region of the 16S rDNA gene of Lactobacillus LF221 was amplified using PCR and sequenced. Primers HDA1 (lacking the GC clamp) and HDA2 were used to amplify the $16 \mathrm{~S}$ rDNA region as outlined by Walter et al. (2000).

\section{Results}

Speciation

The V2-V3 region of 16S rDNA of LF221 (about $200 \mathrm{bp}$ in length) was sequenced and the sequence was compared to sequences from Lactobacillus type strains held in GenBank. According to the perfect match of the V2-V3 sequence of LF221 to the 16S V2-V3 region sequence of GenBank type strain L. gasseri ATCC 33323, LF221 was clearly revealed to be a member of $L$. gasseri species.

Plasmid involvement in acidocin production and curing experiments

To examine the involvement of plasmids in LF221 bacteriocin production, two different protocols were used to isolate plasmid DNA from LF221. However, all attempts to demonstrate the presence of the plasmid DNA in L. gasseri LF221 failed (data not shown). Various methods were used to generate LF221 acidocin-deficient colonies. A total of 1,000 colonies of LF221, grown at $55^{\circ}$ $\mathrm{C}$ for $24 \mathrm{~h}, 48 \mathrm{~h}$ and $72 \mathrm{~h}$, were examined for bacteriocin production. Mutants deficient in LF221 bacteriocin activity were not detected. In addition, 14 days of subculturing LF221 was also ineffective in spontaneous generation of non-bacteriocinogenic variants. However, when 20 colonies, grown in the presence of NTG, were tested for bacteriocin production, one failed to inhibit the indicator strain L. sakei NCDO 2714. This derivative lacking bacteriocin activity (L. gasseri LF221-1) retained the same sugar fermentation pattern using the API 50CHL system (API System, La Balme Les Grottes, France) as the parental strain. Moreover, immunity to the LF221 bacteriocins was retained and the strain was, therefore, characterized by a $\mathrm{Bac}^{-} \mathrm{Imm}^{+}$phenotype (data not shown). The absence of plasmid DNA and the stability of the bacteriocin activity in L. gasseri LF221 suggested that both bacteriocins were chromosomally encoded.
PCR reaction with degenerate primers

Degenerate primers for acidocin LF221 A and B were constructed on the basis of their N-terminal amino acid sequences and used in PCR reactions. Specific PCR fragments of the expected size were obtained when chromosomal DNA of LF221 was used as a template. In the case of acidocin LF221 A the product was $69 \mathrm{bp}$, in the case of acidocin LF221 B 68 bp (data not shown). Moreover, PCR amplicons equal in size were obtained when chromosomal DNA of the $\mathrm{Bac}^{-}$strain was used in the PCR reaction (data not shown). These results suggested that the $\mathrm{Bac}^{-}$mutant still contains the structural genes for both acidocins.

The generated PCR products served as probes (ON-A, ON-B) in further hybridization experiments. Therefore, it was necessary to establish the nucleotide sequence of $\mathrm{ON}$ $\mathrm{A}$ and $\mathrm{ON}-\mathrm{B}$. When the pCR-Blunt recombinant plasmid, carrying the $69 \mathrm{bp}$ amplicon (ON-A) was sequenced, an amino acid sequence from residue 13 to residue 35 of ONA matched with the known amino acid sequence obtained with Edman degradation from the purified acidocin LF221 A. Similarly, the nucleotide sequence of ON-B was shown to be homologous with the amino acid sequence at residues 9-30 determined from the purified peptide acidocin LF221 B (data not shown).

Identification, cloning and characterization of the genetic determinants for acidocin LF221 A and acidocin LF221 B

Chromosomal DNA of LF221 and LF221-1 was subjected to restriction enzyme digestions with BamHI, EcoRI, HindIII, ClaI and BglII and analyzed by Southern hybridization. DIG-labeled ON-A, corresponding to the nucleotides encoding amino acids 13-35 of acidocin LF221 A, was used as a probe in the hybridization. Hybridization of this probe with chromosomal DNA of $L$. gasseri LF221 resulted in a pattern of bands with a strong signal. The 69-bp ON-A probe hybridized to a BamHI fragment of $5 \mathrm{~kb}$, an EcoRI fragment of more than $12 \mathrm{~kb}$, a HindIII fragment of $3.3 \mathrm{~kb}$, a ClaI fragment of $9 \mathrm{~kb}$ and a BglII fragment of $11 \mathrm{~kb}$ in the LF221 chromosome (Fig. 1). Moreover, the same hybridization pattern was obtained with the non-bacteriocinogenic derivative (Fig. 1).

A similar Southern blot with double digests showed that the ON-A probe hybridized to a HindIII/EcoRI fragment of $3.3 \mathrm{~kb}$, a HindIII/BamHI fragment of $0.9 \mathrm{~kb}$, a HindIII/ BglII fragment of $3.3 \mathrm{~kb}$, a HindIII/HaeIII fragment of $2.8 \mathrm{~kb}$ and a HindIII/EcoRV fragment of $3.7 \mathrm{~kb}$ in the LF221 chromosome (data not shown).

Similarly, the structural gene encoding acidocin LF221 B was identified in Southern hybridization using DIGlabeled ON-B as a probe (68 bp), which contains the nucleotides encoding amino acids 9-31 of acidocin LF221 B. As is evident from the Fig. 2, Southern hybridization of single and double digests showed that $\mathrm{ON}-\mathrm{B}$ hybridized to 


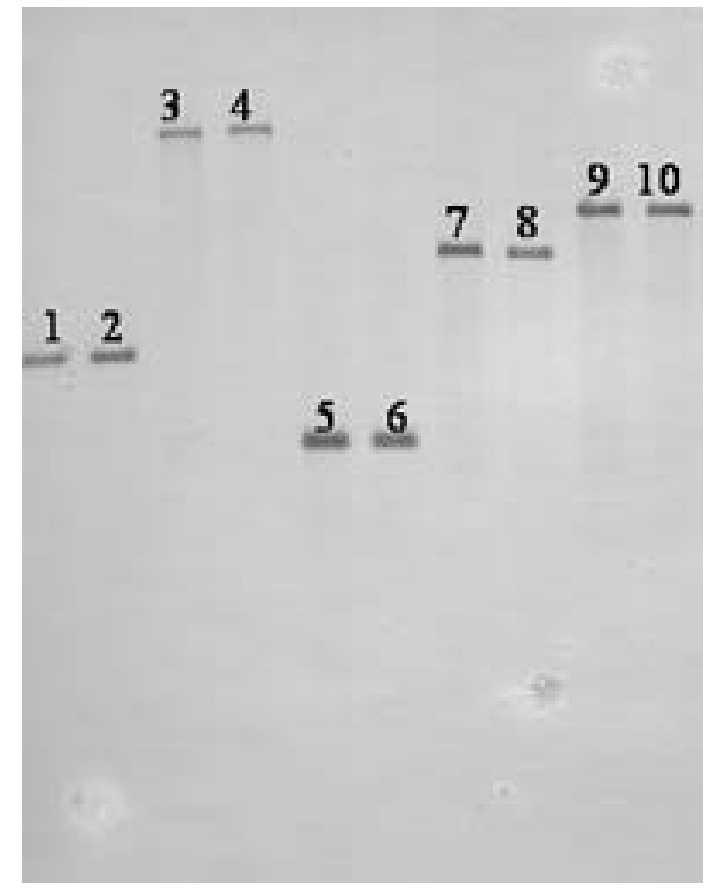

Fig. 1 Results of Southern hybridization with the 69-mer digoxigenin (DIG)-labeled ON-A probe on single-digested chromosomal DNA of Lactobacillus gasseri LF221 $\left(\mathrm{Bac}^{+}\right.$in lanes 1, 3, 5, 7, 9) and LF221-1 ( $\mathrm{Bac}^{-}$in lanes 2, 4, 6, 8, 10). The ON-A probe hybridized to a Bam $\mathrm{HI}$ fragment of $5 \mathrm{~kb}$ (lanes 1, 2), an EcoRI fragment of more than $12 \mathrm{~kb}$ (lanes 3, 4), a HindIII fragment of $3.3 \mathrm{~kb}$ (lanes 5, 6), a ClaI fragment of $9 \mathrm{~kb}$ (lanes 7, 8) and a BglII fragment of $11 \mathrm{~kb}$ (lanes 9, 10)

HindIII and HindIII/BglII fragments of $3 \mathrm{~kb}$, HindIII/ EcoRI, HindIII/EcoRV and EcoRV fragments of $1.8 \mathrm{~kb}$, HindIII/HaeIII and HaeIII fragments of $2 \mathrm{~kb}$, an EcoRI fragment of $4.8 \mathrm{~kb}$ and a $B g l \mathrm{II}$ fragment of $6 \mathrm{~kb}$, respectively, on the LF221 chromosome. From the results of Southern hybridization, the 0.9-kb HindIII/BamHI fragment carrying the structural gene for acidocin LF221 A was chosen for cloning and sequencing, whereas for acidocin LF221 B the 1.8-kb HindIII/EcoRI fragment was chosen.

Total DNA from LF221 was digested with HindIII/ BamHI and electrophoresed on an agarose gel. DNA from the $0.9-\mathrm{kb}$ area of the gel was purified and ligated into the HindIII/BglII-restricted pCR-Blunt. The recombinant plasmids were introduced into $E$. coli JM110 via transformation and approximately 700 clones were screened by colony hybridization. One colony was found to hybridize with the ON-A probe. HindIII/BamHI digests of the recombinant DNA generated the expected $0.9-\mathrm{kb}$ fragment (data not shown). Similarly, the total DNA from LF221 was double-digested with HindIII/EcoRI, electrophoresed and DNA from the $1.8-\mathrm{kb}$ area of the gel was purified. After ligation of the gel-purified DNA to the HindIII/ EcoRI sites of pCR-Blunt, all attempts to transform the recombinant DNA to $E$. coli failed. Using the strategy described in Materials and methods, the ligation mixture of pCR-Blunt::HindIII/EcoRI constructs was subjected to PCR reaction directly, whereby primer pairs BB1/BL2 and

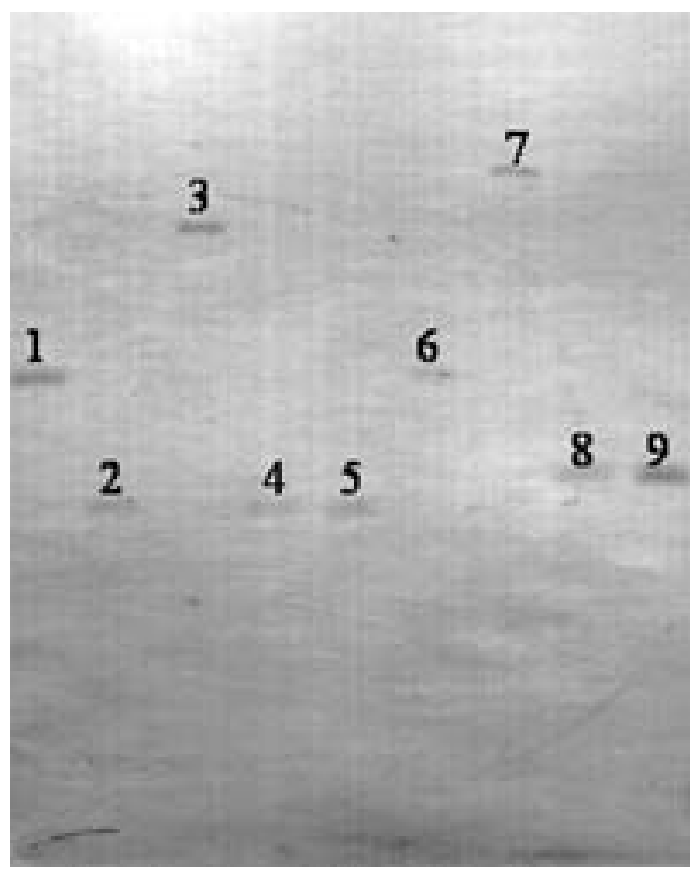

Fig. 2 Results of Southern hybridization with the 68-mer DIGlabeled ON-B probe on single- and double-digested chromosomal DNA of LF221. The ON-B probe hybridized to HindIII and HindIII/ BglII fragments of $3 \mathrm{~kb}$ (lanes 1, 6), HindIII/EcoRI, HindIII/EcoRV and EcoRV fragments of $1.8 \mathrm{~kb}$ (lanes 2, 4, 5) HindIII/HaeIII and HaeIII fragments of $2 \mathrm{~kb}$ (lanes 8, 9), an EcoRI fragment of $4.8 \mathrm{~kb}$ (lane 3) and a BglII fragment of $6 \mathrm{~kb}$ (lane 7)

BB2/BL5 generated specific PCR products of $0.6 \mathrm{~kb}$ and $1.2 \mathrm{~kb}$, respectively, which together formed the $1.8 \mathrm{-kb}$ HindIII/EcoRI fragment carrying the acidocin LF221 B genetic determinants (data not shown). The DNA sequences of the 0.9-kb HindIII/Bam HI fragment containing the acidocin LF221 A gene and the specific PCR products of $0.6 \mathrm{~kb}$ and $1.2 \mathrm{~kb}$ containing the information for acidocin LF221 B gene were determined and analyzed.

Analysis of the nucleotide sequence of the specific regions, carrying the genetic determinants for acidocin LF221 A and acidocin LF221 B, respectively, are shown in Figs. 3, 4.

Sequencing of the 858-bp HindIII/BamHI cloned fragment containing the acidocin LF221 A structural gene revealed two complete open reading frames (ORF) coding for peptides of 69 and 90 amino acids, referred to as orfA2 and orfA3 (Fig. 3). When orfA2 was translated and compared with the amino acid sequence determined from the purified acidocin LF221 A peptide (Bogovič Matijašić et al. 1998), homology of the amino acid residues at positions 17-61 of the predicted acidocin LF221 A was found. Furthermore, the N-terminal extension contained a typical Gly-Gly ${ }^{-1}$ processing site. Thus, orfA2 is the structural gene encoding acidocin LF221 A (Acd221A), consisting of a 16-amino-acid $\mathrm{N}$-terminal extension with a typical Gly-Gly ${ }^{-1}$ doublet and a 53-amino-acid mature bacteriocin. The orfA3, positioned immediately downstream of orfA2, was inferred from the nucleotide sequence. It codes for a peptide of 90 amino acid residues 
$\rightarrow$ Part of OrfAi

CCTTtTt TGGTCAGCCA GTtTCtGTAg GAACAGGTGC ACTAATCGGT GCAAGTGCTG 60 $\begin{array}{llllllllllllllllll}P & V & S & V & G & T & G & A & \text { L } & \text { I } & G & \text { A } & S\end{array}$

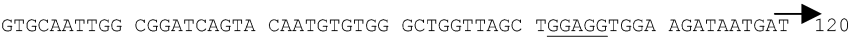
$\begin{array}{lllllllllllllllllllllllllll}G & A & I & G & G & S & V & Q & C & V & G & W & L & A & G & G & G & R & \bullet & M\end{array}$ OrfA2 CGAAAAAgTT TCTAAAAATG AACTAAGCCG GATATATGgT GGAAACAACG TAAATTGGGG 180

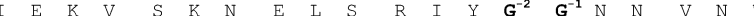

TAgtgtTGCA GGATCATGTG GTAAAgGtgC AgtAAtgGAA ATATATtTCG GGAATCCCAT 240 G S V A G S C G K G A V M E I Y F G N P

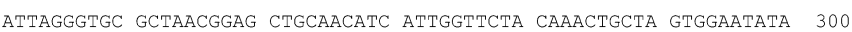

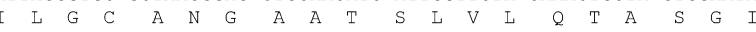

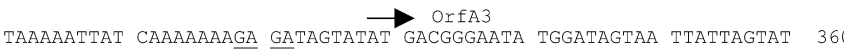
$\begin{array}{lllllllllllllllllllll} & K & N & Y & Q & K & K & R & \bullet & & M & T & G & I & W & I & V & & I & I & S\end{array}$

TATTGTGCTT TCAATAATTA TCACCAATAT AGTAGCTCTA ATACAGACAC TATTACATAA 420 $\begin{array}{llllllllllllllllllllllllll} & I & \mathrm{I} & \mathrm{L} & \mathrm{S} & \mathrm{I} & \mathrm{I} & \mathrm{I} & \mathrm{T} & \mathrm{N} & \mathrm{I} & \mathrm{V} & \mathrm{A} & \mathrm{L} & \mathrm{I} & \mathrm{Q} & \mathrm{T} & \mathrm{L} & \mathrm{L} & \mathrm{H}\end{array}$

GAAAAATGAA AAATATTATT TTGATAAATC TTTTGGAGCC TATGCAGGTA AAAATAATCC 480 $\begin{array}{llllllllllllllllllllll}K & K & N & E & K & Y & Y & E & D & K & S & F & G & A & Y & A & G & K & N & N\end{array}$

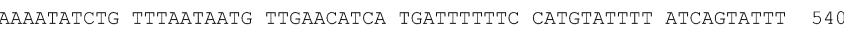
$\begin{array}{llllllllllllllllllllll}\mathrm{P} & \mathrm{K} & \mathrm{Y} & \mathrm{L} & \mathrm{F} & \mathrm{N} & \mathrm{N} & \mathrm{V} & \mathrm{E} & \mathrm{H} & \mathrm{H} & \mathrm{D} & \mathrm{F} & \mathrm{F} & \mathrm{H} & \mathrm{V} & \mathrm{F} & \mathrm{Y} & \mathrm{Q} & \mathrm{Y}\end{array}$

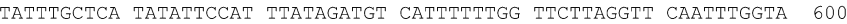
F I C C S

ATAATCAAAA AAGGTCGAAA CTTCATCTTA GTACGAAGTT TCGACCTTTT TTTATTTCAA 660

ATTATTTTAA TTGCTTCCAC GCTGCATCAA ATTTTGCTTT ACCTGCTTTA ATTTGATTAT 720 CAACATTTTG ACCATTCTTA GCTGCATACA AAATCTTAGC CATAATTGGA TCTAATTGAC 780 TGTAGGCAGC GTTTGAGTTC TTAGCTACTG GAATACTGTA CAAGTGTTTC ATAGCCCCTT 840 CTAACTTAGC TGGAAGCT

Fig. 3 Nucleotide sequence of the 0.9-kb BamHI/HindIII fragment from chromosomal DNA of L. gasseri LF221 containing the sequence for the structural gene of acidocin LF221 A. Two possible ribosome-binding sites (RBS) are underlined, whereas the dots indicate three termination codons. The inverted repeat of the putative terminator located downstream of orf $\mathrm{A} 3$ is indicated by the thick line. orf $\mathrm{A} 2$ encodes the structural gene encoding acidocin LF221 A and the bold-marked $G^{-1}$ at nucleotide position 163 shows the cleavage site of the $\mathrm{N}$-terminal extension in the translated peptide

(Aci221A). Five nucleotides downstream of the orfA3 stop codon, an 18-bp inverted repeat acting as a probable transcriptional terminator was found. DNA analysis of the cloned HindIII/BamHI fragment revealed a part of a third possible ORF (orfA1') located upstream of orfA2 and currently consisting of 37 amino acid residues. Putative ribosomal binding sites (RBS) were identified upstream of orfA2 and orfA3. Figure 4 shows the results of the analysis of the nucleotide sequence of the 1,772-bp HindIII/EcoRI fragment with one incomplete and four complete ORFs, including the structural gene for acidocin LF221 B. All four complete ORFs are preceded by a typical RBS at a distance of 6-10 nucleotides before the translation start codon. Thirty-five amino acids of the purified acidocin LF221 B corresponded to the sequence found in $\operatorname{orf} \mathrm{B} 4$, starting with $\mathrm{Asn}^{18}$. The nucleotide

Fig. 4 Nucleotide sequence of the 1.8-kb EcoRI/HindIII fragment from chromosomal DNA of L. gasseri LF221 containing the sequence for the structural gene of acidocin LF221 B. Framed nucleotides indicate possible promoter sequences. Four putative RBS are underlined, whereas the dots indicate five termination codons. The inverted repeats of the putative terminators located downstream of $\operatorname{orf} \mathrm{B} 1, \operatorname{orf} \mathrm{B} 2$ and $\operatorname{orf} \mathrm{B} 5$ are indicated by the thick lines. OrfB3 and OrfB4 are the complementary peptides of the acidocin LF221 B and the structural gene encoding acidocin LF221 $\mathrm{B}$, respectively, whereas the bold-marked $G^{-1}$ indicate the cleavage sites of the N-terminal extensions. OrfB5 is the putative immunity gene sequence revealed that the mature acidocin LF221 B consists of 48 amino acid residues in total and is formed after the cleavage of the N-terminal extension at the Gly$\mathrm{Gly}^{-1}$ motif site from the 65-amino-acid precursor $(\mathrm{Acd} 221 \mathrm{~B})$. The $\operatorname{orfB} 3$, positioned directly upstream of acidocin LF221 B gene (orfB4), encodes a peptide of 75 amino acids. The first 18 amino acids of this ORF also resemble a leader peptide of the double-glycine type with typical hydrophobic amino acids found at positions -4 ,

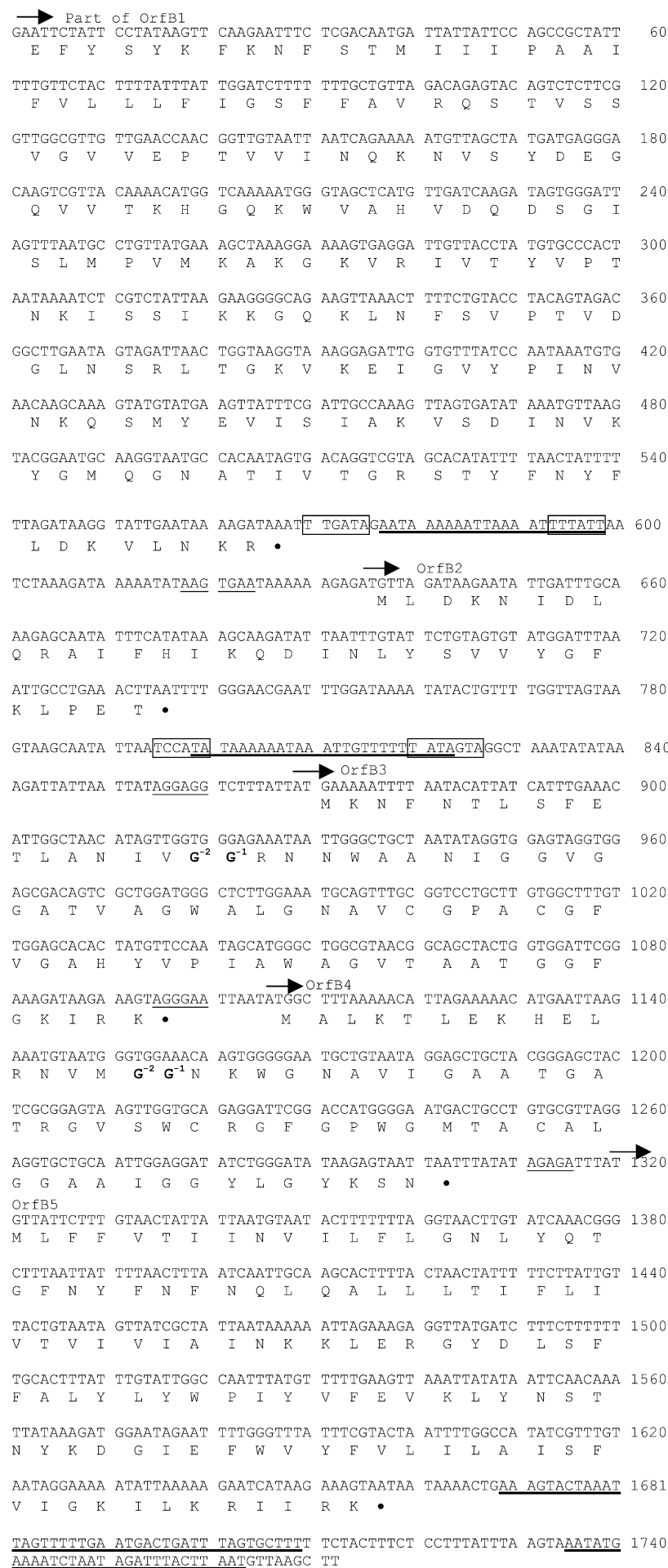


-7 and -12 and Ser at -11 . The leader sequence is followed by 57 amino acids, which could represent the second component of the two-peptide bacteriocin $(\mathrm{Acd} 221 \beta)$. orfB4 is followed by a peptide of 112 amino acids (orfB5). No Gly-Gly ${ }^{-1}$ type leader peptide is contained, suggesting that orf $\mathrm{B} 5$ might encode for an immunity protein (Aci221B). Downstream of orfB5 there are two regions, which could form imperfect stemloop structures. Since no putative terminator or promoter sequences were found between ORFs B3, B4 and B5, they are presumed to form an operon. Two more inverted repeat sequences were located on the 1,772-bp fragment. These two putative terminators overlap with promoter regions that are found upstream of $\operatorname{orf} \mathrm{B} 2$ and $\operatorname{orf} \mathrm{B} 3$. orf $\mathrm{B} 2$ is translated as a short peptide of 33 amino acids, while orf $\mathrm{B}^{\prime}$ is not complete and extends from nucleotide position 1 to position 567 .

Alignment of the leader peptides of Acd221A, Acd221B and Acd221 $\beta$ with the N-terminal extensions of other class II bacteriocins strengthens our assumption that acidocin LF221 A and acidocin LF221 B are bacteriocins. As is evident from Fig. 5, the N-terminal extension of Acd221A shares a high degree of homology with the leader peptides of BrcB, LcnN and ThmB. Similarly, Acd221B and Acd $221 \beta$ are highly homologous not only to GatX/LafX and GatA/LafA peptides, respectively, but also to each other's N-terminal leaders (Fig. 6).

\section{Discussion}

L. gasseri LF221 is a member of the B1 DNA homology group of L. acidophilus (Johnson et al. 1980). Very little information about $L$. gasseri bacteriocins is available to date. Only gassericin T produced by L. gasseri SBT2055 (Kawai et al. 2000), gassericin A produced by L. gasseri LA39 (Kawai et al. 1998), two other bacteriocins produced by L. gasseri JCM 2124 (Tahara et al. 1997) and a bacteriocin from L. gasseri KT7 (Zhu et al. 2000) have been investigated. The present study summarizes the genetic characteristics of acidocin LF221 A and acidocin LF221 B, two different proteinaceous antimicrobials produced by L gasseri LF221. It is not a rare event that one strain produces two or more different bacteriocins. Among the bacteriocinogenic bacteria that produce more than one biologically active peptide, we find L. lactis subsp. cremoris 9B4 (van Belkum et al. 1989), L. plantarum LPCO10 (Jimenez-Diaz et al. 1993), Carno-

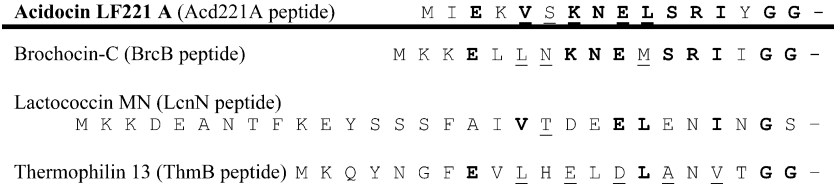

Fig. 5 Amino acid comparison of the N-terminal leader of acidocin LF221 A to the N-terminal leaders of other class II lactic acid bacteria (LAB) bacteriocins: brochocin-C (McCormick et al. 1998), lactococcin MN (van Belkum et al. 1991), thermophilin 13 (Marciset et al. 1997). Identical amino acid residues are marked in bold and similar amino acids are underlined

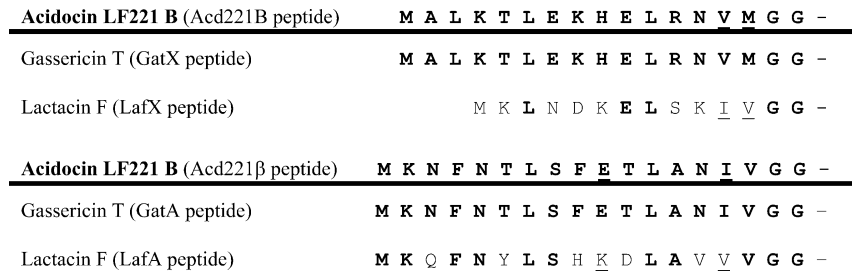

Fig. 6 Amino acid comparison of the N-terminal leader of acidocin LF221 $\mathrm{B}$ to the N-terminal leaders of other class II LAB bacteriocins: gassericin $\mathrm{T}$ (Kawai et al. 2000) and lactacin $\mathrm{F}$ (Allison et al. 1994). Identical amino acid residues are marked in bold, and similar amino acids are underlined

bacterium piscicola LV17B (Quadri et al. 1994), L. acidophilus LMG P-13139 (Contreras et al. 1997), Enterococcus faecalis BFE 1071 (Balla et al. 2000), Leuconostoc mesenteroides subsp. mesenteroides FR52 (Revol-Junelles et al. 1996) and E. faecium P21 (Herranz et al. 2001).

Structural genes for bacteriocins of Lactobacillus acidophilus and related strains can be plasmid-located, such as acidocin 8912, acidocin A and acidocin B (Kanatani et al. 1995a, 1995b; van der Vossen et al. 1994), or they can be found on the chromosome. Examples for this are lactacin B (Barefoot and Klaenhammer 1983, 1984), gassericin A (Kawai et al. 1998) and gassericin T (Kawai et al. 2000). However, the lactacin F genetic determinants are located on a conjugative transposon (Muriana and Klaenhammer 1987). Bacteriocin production and immunity can be unstable if their genetic determinants are plasmid-encoded. The genes encoding bacteriocins in L. gasseri LF221 appear to be chromosomally located. All attempts to isolate plasmid DNA failed; and the $\mathrm{Bac}^{+}$phenotype was stable under a variety of curing treatments. Only NTG treatment generated one $\mathrm{Bac}^{-}$derivative that retained immunity to the LF221 bacteriocins and had the same fermentation pattern as the parental $\mathrm{Bac}^{+}$strain. Moreover, it is supposed that at least portions of the acidocin LF221 A and B structural genes are still present in the $\mathrm{Bac}^{-}$isolate, as Southern analyses generated hybridizing fragments of the same size as with chromosomal DNA of the $\mathrm{Bac}^{+}$strain. If so, the mutation caused by NTG treatment might have occurred on the secretion and/or expression level.

Extensive analyses of the 858-bp HindIII/BamHI fragment with the structural gene encoding for acidocin LF221 A and the 1,772-bp HindIII/EcoRI fragment containing the acidocin LF221 B genetic determinants indicate that these are members of class II LAB proteinaceous antimicrobials. No unusual amino acids, such as lanthionine or $\beta$ methillanthionine residues, were noticed and all previously reported biochemical characteristics of acidocins LF221 A and B as small, heat-stable and hydrophobic peptides support their classification as non-lantibiotics (Bogovič Matijašić et al. 1998). The sequences of the putative peptides found on the 858-bp and 1,772-bp fragments of the LF221 chromosomal DNA were compared with already known and described sequences deposited at NCBI, using the BLAST network service. 
These searches revealed that, from the 858-bp fragment, orfA2 appears to encode a 69-amino-acid precursor that very likely undergoes proteolytic cleavage of a 16aminoacid N-terminal leader peptide. The processed mature acidocin LF221 A (Acd221A) consisting of 53 amino acids is partially identical to the mature peptides BrcB (52\% identity), LcnN (39\% identity) and ThmB (32\% identity). The BrcB, LcnN and ThmB peptides, complemented with BrcA, LcnM and ThmA, respectively, form the two-component bacteriocins known as brochocin-C (McCormick et al. 1998), lactococcin MN (van Belkum et al. 1991) and thermophilin13 (Marciset et al. 1997) that are recognized as class II bacteriocins, where a high degree of homology with N-terminal extensions of same peptides is of no exception (Fig. 5). A conserved double-glycine consensus, typical for the class II bacteriocins, is found at positions -2 and -1 with regard to the processing site. Other conserved amino acid residues of the leader peptides of these bacteriocins were also identified: hydrophobic amino acid residues were found at positions $-4(\mathrm{I}),-7(\mathrm{~L}),-12(\mathrm{~V})$ and $-15(\mathrm{I})$ while conserved hydrophilic amino acid were positioned at -8 (E), $-9(\mathrm{~N})$ and $-11(\mathrm{~S})$ (Havarstein et al. 1994). Downstream of the structural gene, orfA3 is located, encoding a protein of 90 amino acids. The role of this putative protein remains unknown at present, but it is very likely to code for an immunity protein (Aci221A) because, for all bacteriocin operons studied so far, immunity genes have been located next to and downstream of the bacteriocin structural genes. Moreover, the length of orfA3 (90 amino acids) is in the expected range for class II bacteriocin immunity proteins (Nes et al. 1996), while computer analysis (TopPred2) of the primary amino acid sequence of the Aci221A protein revealed two putative transmembrane helices (data not shown), which are common for immunity proteins (Nes et al. 1996). Part of a third probable ORF (orf $\left.\mathrm{A}^{\prime}\right)$ was identified and the primary structure of the possible peptide was deduced from the DNA composition. Among the 37 amino acids identified so far, almost half of them are small amino acids, such as Gly, Ala and Ile, which is a common feature for class II bacteriocins (Klaenhammer 1993). This can lead to the assumption that orf $\mathrm{A}^{\prime}$ ' might in fact encode a second component $($ Acd $221 \alpha)$ of the acidocin LF221 A, required for its activity. Moreover, no putative promoter and terminator sequences were found between or upstream of orfA1', orf $\mathrm{A} 2$ and orfA3, indicating that all three ORFs may be organized in the same operon structure. This speculation is supported by the fact that acidocin LF221 A shows some homologies only to two-component bacteriocins (brochocin-C, lactococcin $\mathrm{MN}$ and thermophilin 13) which are all confirmed as subclass B of class II bacteriocins, consisting of two peptides needed for activity (Klaenhammer 1993). When the ORFs of the 1,772-bp fragment with the acidocin LF221 B structural gene were subjected to homology searches, a certain degree of homology was found between OrfB3 (Acd221 $\beta)$ and OrfB4 (Acd221B) proteins and the published LafA and LafX (62\% and 55\%, respectively), which together form lactacin $\mathrm{F}$ produced by
L. johnsonii (Allison et al. 1994). Furthermore, the most interesting result is that the complete sequence of the 1,772-bp HindIII/EcoRI fragment exerts nearly $100 \%$ homology to the corresponding fragment of the recently reported sequence of a 2,874-bp HindIII fragment with the gassericin T structural genes (Kawai et al. 2000). ORFs B3, B4 and B5 have $100 \%, 98 \%$ and $100 \%$ identity to GatA, GatX and the putative immunity protein, respectively, from L. gasseri SBT2055. Further analysis of OrfB5 (Aci221B), a putative immunity factor for the acidocin LF221 B system, revealed 34\% identity to LafI peptide, which has already been confirmed as an immunity protein for the lactacin F complex (Allison and Klaenhammer 1996). Besides, Aci221B is similar to LafI in size (112 amino acids and 124 amino acids, respectively) and in the number of predicted transmembrane helices (four in each peptide). orf $\mathrm{B} 2$ from the 1,772-bp fragment is $100 \%$ identical to the ORF3 from the 2,874-bp fragment from $L$. gasseri SBT2055, which is suspected to be the expression regulator for gassericin $\mathrm{T}$, while orf $\mathrm{B} 11^{\prime}$ encodes a truncated peptide of 188 amino acid residues which revealed some homologies to accessory factors for ABCtransporters found in some lactobacilli. The structural gene for acidocin LF221 B is located as orfB4 on the 1,772-bp HindIII/EcoRI fragment of the chromosomal DNA and is accompanied by its putative immunity gene (orfB5) and a putative second component (orfB3) for acidocin LF221 B activity, indicating a gene cluster typical and most often described for bacteriocins of class II. N-terminal extensions of both $\operatorname{orf} \mathrm{B} 3$ and $\operatorname{orf} \mathrm{B} 4$ contain the Gly-Gly doublet, hydrophobic amino acid residues at positions -4 , -7 and -12 , charged amino acids at -8 and -10 , Ser at -11 and are highly homologous to the GatA and LafA and the GatX and LafX N-terminal extensions (Fig. 6). Taken together with the partial homology to lactacin F and actual identity to gassericin $\mathrm{T}$, it seems likely that acidocin LF221 B, the second of two bacteriocins produced by $L$. gasseri LF221, belongs to subgroup B of class II bacteriocins.

Acd221A is partially homologous only to bacteriocins with a broad inhibitory spectrum. Earlier research revealed that the LF221 bacteriocin complex expresses an unusually wide inhibitory activity, including some spoilage and pathogenic bacteria (Bogovič Matijašić et al. 1998), where both acidocins probably contribute together. It is known that the combined action of several bacteriocins is greater than that of each bacteriocin separately. Although there is no information yet available on the inhibitory action of LF221 acidocins separately, it cannot be excluded that acidocin LF221 A may somehow be the one that mostly contributes to the broad antibacterial activity of the LF221 strain.

Despite the obvious identity between acidocin LF221 B and gassericin $\mathrm{T}$, there is at least one interesting remark to be made. The mature GatA (gassericin T) protein, which was detected in the supernatant, shows identity with the protein encoded by orf $\mathrm{B} 3$ from the HindIII/EcoRI region of LF221, which in our instance was not detected as an active component in the MRS supernatant, but was 
revealed from the translated nucleotide sequence only. In contrast, the active acidocin LF221 B (orfB4) resembles GatX, which in gassericin T represents the complementary component to GatA and was deduced from the sequencing analysis and not found in the culture supernatant. This suggests that acidocin LF221 B and gassericin T differ in certain characteristics other than the sequence, as was also shown for amylovorin L471 and lactobin A. Callewaert et al. (1999) determined 35 amino acid residues of amylovorin L471 produced by L. amylovorus DCE 471 that were identical to the N-terminal amino acid sequence of lactobin A, a bacteriocin from another L. amylovorus strain (Contreras et al. 1997). Although amylovorin L471 and lactobin A seem to be homologously produced by two different strains, certain discrepancies appeared, for instance between their inhibitory spectra, which the researchers found difficult to explain. Callewaert and coworkers suspected that the absence (lactobin A)/presence (amylovorin L471) of a disulfide bridge might be the reason for the difference in antimicrobial spectra. Thus, in spite of virtual DNA homology between acidocin LF221 B and gassericin $\mathrm{T}$, certain differences in activities in the supernatant can be observed. For example, active acidocin LF221 B exerts identity to GatX, which was not detected as an active peptide in supernatant; and the inactive component of acidocin LF221 B showed homology to the active peptide of gassericin T. To clarify the question concerning the contribution of each acidocin to the mutual antibacterial activity of the parental LF221 bacteriocin complex, expression studies with acidocin LF221 A and $\mathrm{B}$, respectively, must be completed. At the same time, cloning of larger fragments with close examination of the vicinal regions could provide some explanations about the eventual disparities between the acidocin LF221 B and gassericin $\mathrm{T}$. When the enterocin A produced by $E$. faecium P21 and the enterocin A of E. faecium CTC 429 were recognized to be identical, only a comparison of larger regions revealed that the EntA operon in E. faecium P21 in fact differs structurally from the EntA operon in $E$. faecium CTC492. This may be sufficient for certain differences in activities observed between both strains (Herranz et al. 2001). Since Lactobacillus LF221 and Lactobacillus SBT2055 are isolates from the same ecological niche (an infant's feces) and are members of the gasseri species, it is not surprising that earlier-stated relations are found between them and their bacteriocins acidocin LF221 B and gassericin T. Of course, it may appear that L. gasseri LF221 and L. gasseri SBT2055 are identical strains, but differences in the inhibitory spectrum reported for each strain (Kawai et al. 1997; Bogovič Matijašić et al. 1998) and the fact that SBT2055 produces only one bacteriocin, whereas LF221 produces at least two bacteriocins, indicate that SBT2055 and LF221 may differ on the strain level. Nevertheless, it seems that a broad spectrum of antimicrobial activity and production of bacteriocins classifies L. gasseri LF221 among the promising candidates for use in food and feed preservation. Equally important, with regard to its human origin, LF221 represents a possible probiotic adjunct in fermented foods and in therapeutic preparations. For this purpose, persistence and survival studies of LF221 in different ecosystems were recently performed (Rogelj et al. 2002). Genetic description of acidocins LF221 A and B now provides opportunities to investigate these bacteriocins in a variety of applications and ecological scenarios.

Acknowledgements. We thank the Slovenian Ministry of Science and Technology for funding the work presented (contract 3411-9724-7446). The majority of the molecular biology experiments were accomplished in the laboratory of the Department of Food Science, North Carolina State University.

\section{References}

Allison GE, Klaenhammer TR (1996) Functional analysis of the gene encoding immunity to lactacin F, lafl, and its use as a Lactobacillus-specific, food-grade genetic marker. Appl Environ Microbiol 62:4450-4460

Allison GE, Fremaux C, Klaenhammer TR (1994) Expansion of bacteriocin activity and host range upon complementation of two peptides encoded within the lactacin F operon. J Bacteriol 176:2235-2241

Balla E, Dicks LMT, Toit M du, Merwe MJ van der, Holzapfel WH (2000) Characterization and cloning of the genes encoding enterocin 1071A and enterocin 1071B, two antimicrobial peptides produced by Enterococcus faecalis BFE 1071. Appl Environ Microbiol 66:1298-1304

Barefoot SF, Klaenhammer TR (1983) Detection and activity of lactacin B, a bacteriocin produced by Lactobacillus acidophilus. Appl Environ Microbiol 45:1808-1815

Barefoot SF, Klaenhammer TR (1984) Purification and characterization of the Lactobacillus acidophilus bacteriocin lactacin B. Antimicrob Agents Chemother 26:328-334

Belkum MJ van, Hayema BJ, Geis A, Kok J, Venema G (1989) Cloning of two bacteriocin genes from a lactococcal bacteriocin plasmid. Appl Environ Microbiol 55:1187-1191

Belkum MJ van, Hayema BJ, Jeeninga RE, Kok J, Venema G (1991) Organization and nucleotide sequences of two lactococcal bacteriocin operons. Appl Environ Microbiol 57:492-498

Birnboim HC, Doly J (1979) A rapid alkaline extraction procedure for screening recombinant plasmid DNA. Nucleic Acids Res 7:1513-1523

Bogovič Matijašić B, Rogelj I, Nes IF, Holo H (1998) Isolation and characterisation of two bacteriocins of Lactobacillus acidophilus LF221. Appl Microbiol Biotechnol 49:606-612

Callewaert R, Holo H, Devreese B, Van Beeumen J, Nes I, Vuyst L de (1999) Characterization and production of amylovorin L471, a bacteriocin purified from Lactobacillus amylovorus DCE 471 by a novel three-step method. Microbiology 145:2559-2568

Contreras BGL, Vuyst L de, Devreese B, Busanyova K, Raymaeckers J, Bosman F, Sablon E, Vandamme EJ (1997) Isolation, purification, and amino acid sequence of lactobin A, one of the two bacteriocins produced by Lactobacillus amylovorus LMG P-13139. Appl Environ Microbiol 63:13-20

Dinsmore PK, Klaenhammer TR (1997) Molecular characterization of a genomic region in a Lactococcus bacteriophage that is involved in its sensitivity to the phage defense mechanism AbiA. J Bacteriol 179:2949-2957

Fujisawa T, Benno Y, Yaeshima T, Mitsuoka T (1992) Taxonomic study of the Lactobacillus acidophilus group, with recognition of Lactobacillus gallinarium sp. nov. Lactobacillus johnsonii sp. nov. and synonymy of Lactobacillus acidophilus group A3 (Johnson et al., 1980) with the type strain of the Lactobacillus amylovorus (Nakamura, 1981). Int J Syst Bacteriol 32:487-491

Gergen JP, Stern RH, Wensink PC (1979) Filter replicas and permanent collections of recombinant DNA plasmids. Nucleic Acids Res 7:2115-2136 
Havarstein LS, Holo H, Nes IF (1994) The leader peptide of colicin $\mathrm{V}$ shares consensus sequence with leader peptides that are common among peptide bacteriocins produced by Grampositive bacteria. Microbiology 140:2383-2389

Heilig HG, Zoetendal EG, Vaughan EE, Marteau P, Akkermans AD, Vos WM de (2002) Molecular diversity of Lactobacillus spp and other lactic acid bacteria in the human intestine as determined by specific amplification of $16 \mathrm{~S}$ ribosomal DNA. Appl Environ Microbiol 68:114-123

Herranz C, Casaus P, Mukhopadhyay S, Martinez JM, Rodriguez JM, Nes IF, Hernandez PE, Cintas LM (2001) Enterococcus faecium P21: a strain occurring naturally in dry-fermented sausages producing the class II bacteriocins enterocin A and enterocin B. Food Microbiol 18:115-131

Jimenez-Diaz R, Rios-Sanchez RM, Desmazeaud M, Ruiz-Barba JL, Piard JC (1993) Plantaricins S and T, two new bacteriocins produced by Lactobacillus plantarum LPCO10 isolated from a green olive fermentation. Appl Environ Microbiol 59:14161424

Johnson JL, Phelps CF, Cummins CS, London J, Gasser F (1980) Taxonomy of the Lactobacillus acidophilus group. Int J Syst Bacteriol 30:53-68

Kanatani K, Tahara T, Oshimura M, Sano K, Umezawa C (1995a) Cloning and nucleotide sequence of the gene for acidocin 8912, a bacteriocin from Lactobacillus acidophilus TK8912. Lett Appl Microbiol 21:384-386

Kanatani K, Oshimura M, Sano K (1995b) Isolation and characterization of acidocin A and cloning of the bacteriocin gene from Lactobacillus acidophilus. Appl Environ Microbiol 61:1061-1067

Kawai Y, Saito T, Uemura J, Itoh T (1997) Rapid detection method for bacteriocin and distribution of bacteriocin-producing strains in Lactobacillus acidophilus group lactic acid bacteria isolated from human feces. Biosci Biotechnol Biochem 61:179-182

Kawai Y, Saito T, Suzuki M, Itoh T (1998) Sequence analysis by cloning of the structural gene of gassericin A, a hydrophobic bacteriocin produced by Lactobacillus gasseri LA39. Biosci Biotechnol Biochem 62:887-892

Kawai Y, Saito B, Takahashi O, Kitazawa H, Saito T, Nakajima H, Itoh T (2000) Primary amino acid and DNA sequences of gassericin $\mathrm{T}$, a lactacin $\mathrm{F}$-family bacteriocin produced by Lactobacillus gasseri SBT2055. Biosci Biotechnol Biochem 64:2201-2208

Klaenhammer TR (1984) A general method for plasmid isolation in lactobacilli. Curr Microbiol 10:23-28

Klaenhammer TR (1993) Genetics of bacteriocins produced by lactic acid bacteria. FEMS Microbiol Rev 12:39-86

Leenhouts KJ, Kok J, Venema G (1990) Stability of integrated plasmids in the chromosome of Lactococcus lactis. Appl Environ Microbiol 56:2726-2735

Leer RJ, Vossen JMBM van der, Griezen M van, Noort JM van, Pouwels PH (1995) Genetic analysis of acidocin B, a novel bacteriocin produced by Lactobacillus acidophilus. Microbiology 141:1629-1635

Man JC de, Rogosa M, Sharpe E (1960) A medium for the cultivation of Lactobacilli. J Appl Bacteriol 23:130-135

Marciset O, Jeronimus-Stratingh MC, Mollet B, Poolman B (1997) Thermophilin 13, a nontypical antilisterial poration complex bacteriocin, that functions without a receptor. J Biol Chem 272:14277-14284
McCormick JK, Poon A, Sailer M, Gao Y, Roy KL, McMullen LM, Vederas JC, Stiles ME, Belkum MJ van (1998) Genetic characterization and heterologous expression of brochocin-C, an antibotulinal, two-peptide bacteriocin produced by Brochothrix campestris ATCC 43754. Appl Environ Microbiol 64:4757-4766

Mitsuoka T (1992) The human gastrointestinal tract. In: Wood BJB (ed) The lactic acid bacteria, vol 1. The lactic acid bacteria in health and disease. Elsevier Applied Science, London, pp 69 114

Moll GN, Konings WN, Driessen AJM (1999) Bacteriocins: mechanism of membrane insertion and pore formation. Antonie Van Leeuwenhoek 76:185-198

Muriana PM, Klaenhammer TR (1987) Conjugal transfer of plasmid-encoded determinants for bacteriocin production and immunity in Lactobacillus acidophilus 88. Appl Environ Microbiol 53:553-560

Nes IF, Diep DB, Havarstein LS, Brurberg MB, Eijsink V, Holo H (1996) Biosynthesis of bacteriocins in lactic acid bacteria. Antonie Van Leeuwenhoek 70:113-128

Quadri LEN, Sailer M, Roy KL, Vederas JC, Stiles ME (1994) Chemical and genetic characterization of bacteriocins produced by Carnobacterium piscicola LV17B. J Biol Chem 269:1220412211

Revol-Junelles AM, Mathis R, Krier F, Fleury Y, Delfour A, Lefebvre G (1996) Leuconostoc mesenteroides subsp. mesenteroides FR52 synthesizes two distinct bacteriocins. Lett Appl Microbiol 23:120-124

Rogelj I, Bogovič Matijašić B, Čanžek Majhenič A, Stojković S (2002) The survival and persistence of Lactobacillus acidophilus LF221 in different ecosystems. Int J Food Microbiol 76:83-91

Sambrook J, Fritsch EF, Maniatis T (1989) Molecular cloning: a laboratory manual, 2nd edn. Cold Spring Harbor Laboratory Press, Cold Spring Harbor, N.Y.

Sanger F, Nicklen S, Coulson AR (1977) DNA sequencing with chain-terminating inhibitors. Proc Natl Acad Sci USA 74:5463-5467

Tagg JR, Dajani AS, Wannamaker LW (1976) Bacteriocins of grampositive bacteria. Bacteriol Rev 40:722-756

Tahara T, Yoshioka S, Utsumi R, Kanatani K (1997) Isolation and partial characterization of bacteriocins produced by Lactobacillus gasseri JCM 2124. FEMS Microbiol Lett 148:97-100

Teuber M, Meile L, Schwarz F (1999) Acquired antibiotic resistance in lactic acid bacteria from food. Antonie Van Leeuwenhoek 76:115-137

Vossen JMBM van der, Herwijnen MHM van, Leer RJ, Brink B ten, Pouwels PH, Huis in't Veld JHJ (1994) Production of acidocin B, a bacteriocin of Lactobacillus acidophilus M46 is a plasmidencoded trait: plasmid curing, genetic marking by in vivo plasmid integration, and gene transfer. FEMS Microbiol Lett $116: 333-340$

Walter J, Tannock GW, Tilsala-Timisjarvi A, Rodtong S, Loach DM, Munro K, Alatossava T (2000) Detection and identification of gastrointestinal Lactobacillus species by using denaturing gradient gel electrophoresis and species-specific PCR primers. Appl Environ Microbiol 66:297-303

Yanisch-Perron C, Vieira J, Messing J (1985) Improved M13 phage cloning vectors and host strains: nucleotide sequences of the M13mp18 and pUC 19 vectors. Gene 33:103-119

Zhu WM, Liu W, Wu DQ (2000) Isolation and characterization of a new bacteriocin from Lactobacillus gasseri KT7. J Appl Microbiol 88:877-886 